\title{
TRENDS OF ATMOSPHERIC HEAVY METAL DEPOSITION IN LITHUANIA
}

\author{
K. Kvietkus, J. Šakalys, and D. Valiulis \\ State Research Institute Center for Physical Sciences and Technology, Savanoriu 231, LT-02300 Vilnius, Lithuania \\ E-mail: kvietkus@ktl.mii.lt
}

Received 28 July 2011; revised 28 November 2011; accepted 1 December 2011

\begin{abstract}
The results of long-term measurements of heavy metal $(\mathrm{Pb}, \mathrm{Zn}, \mathrm{Cr}, \mathrm{Ni}, \mathrm{Cu}, \mathrm{Mn}, \mathrm{Cd}, \mathrm{Fe}, \mathrm{As}, \mathrm{Hg}$ ) concentrations carried out at the Aukštaitija and Žemaitija integrated monitoring stations (IMS) are presented in this work. The average annual concentrations of heavy metals in the air in 2007-2008 and in precipitation over the period 2006-2010 are analysed. A higher deposited amount of heavy metals on the Earth's surface was determined in the western part of Lithuania (Žemaitija IMS) compared with the eastern part of Lithuania (Aukštaitija IMS). Different deposited amounts of heavy metals are related to higher concentration of heavy metals in the air and higher amounts of precipitation in the western part of Lithuania. A decreasing trend of $\mathrm{Pb}$ concentration in precipitation and an increasing trend for $\mathrm{Cr}, \mathrm{Ni}$ and $\mathrm{Cu}$ in precipitation and deposited amounts were observed at both stations. Common correlating groups of element concentrations for both stations were established: $\mathrm{As}-\mathrm{Cd}$, $\mathrm{Ni}-\mathrm{Cr}-\mathrm{Cu}$, and $\mathrm{Mn}-\mathrm{Cu}$. These groups are probably typical of the entire territory of Lithuania and are caused by long-range transfer of air masses.
\end{abstract}

Keywords: heavy metals, concentration, air, precipitation, deposition, trend

PACS: 92.60.Sz, 92.60.Fm, 92.60.Jq, 92.70.Cr

\section{Introduction}

Heavy metals are emitted into the atmosphere due to industrial, motor transport and volcanic activities, soil erosion, forest fires, evaporation, etc. [1]. Most of metals in the air are in particulate form with the exception of mercury $(\mathrm{Hg})$. Usually, toxic metals such as $\mathrm{Pb}, \mathrm{Cd}$, As are found in fine particles $(<2.5 \mu \mathrm{m})$. Fine particles are respirable and tend to persist in the atmosphere where they can undergo chemical reactions and be transported from their sources over long distances to pristine areas of the environment [2-6]. Most of heavy metals are soluble in water, thus they can migrate in ecosystems by water pathways. Even small amounts and low concentrations of heavy metals can damage ecosystems and are dangerous for human health $[7,8]$. Therefore, it is important to know the amount and trends of deposited toxic compounds on the Earth's surface.

Wet and dry deposition is the main process for the removal of particulate metals from the atmosphere and in areas affected by long-range transport of air masses. Direct investigations of chemical compounds in precipitation are always complicated and uncertain in many cases. It is determined that about $40-90 \%$ of heavy metals are removed from the atmosphere with wet depositions $[9,10]$. Linear relationships between the scavenging coefficients and rain intensity for different aerosol size are observed in [11]. Studies devoted to investigations of atmospheric trace metal deposition are scarce for Central and Eastern European regions [12]. There is a lack of studies where the influence of deposition of long-range transported elements is analysed. During their passage, air masses undergo many transformations which should significantly influence metal concentrations in the air. Experimental results indicated that every location selected for monitoring of pollutants should be evaluated for a possible influence of local sources. Local sources can significantly alter heavy metal concentrations and may be the reason for contrasting results [13].

Anthropogenic emission of heavy metals is not high on the Lithuanian territory, as was shown in our previous paper [14]. The analysis of results 
showed that about $10-30 \%$ of pollutant amount is washed out by precipitation on the Lithuanian territory. According to the calculations, about $70-90 \%$ of pollutants are long-range transported with air masses from Western and Central Europe [15].

Leaded petrol has gradually been ruled out in Europe since 1987 (since 1993 in Lithuania). The application of advanced technologies in Western Europe influenced the air quality in Lithuania. Lead concentration decreased about six times in the atmosphere in Lithuania during 1993-2002 [14]. The rate of emission of some metals $(\mathrm{Cd}, \mathrm{Pb}, \mathrm{Zn})$ substantially decreased, metal concentrations in the air and in atmospheric depositions dropped with decreased emissions.

During the past decade, a number of studies on atmospheric deposition trends of heavy metals in different areas were published [16-21]. $\mathrm{Pb}$ levels were reduced by about $25 \%$ during the period 1982-1995, and a slight decreasing trend was found for $\mathrm{Co}$ and $\mathrm{Hg}$ during the same period. Most of mercury in soil is due to atmospheric deposition, mainly from anthropogenic sources [22]. Deposition of heavy metals is better investigated in background areas than in urban ones. The global pattern shows a decrease of fluxes for most of elements in Paris area during the period 1994-2002 [23].

Recently, a number of studies on spatial, seasonal and annual variations of heavy metal concentrations in ambient air, precipitation and mosses have been published [24-28]. Some results indicated a strong dependence of heavy metal concentration in the air and in precipitation on the amount of precipitation. In general, there are different trends in different regions: atmospheric depositions of most metals were significantly elevated in China compared with other regions, e. g. the Great Lakes region in North America and Northern Europe. The moss method provides a cheap alternative to deposition analysis for identification of areas at risk from high atmospheric deposition fluxes of heavy metals and temporal trends of atmospheric heavy metal deposition across Europe at high resolution. However, it is important to continue studies of heavy metal deposition processes because new anthropogenic sources or increasing emission from other regions may appear.

The aim of the study is to provide variation trends of heavy metal concentrations in the atmospheric deposition and to evaluate possible quantitative changes in Lithuania during the period 2006-2010.

\section{Material and methods}

\subsection{Sampling sites and sampling methodology}

Precipitation samples were collected at Aukštaitija and Žemaitija integrated monitoring stations (IMS) in Lithuania (see Fig. 1). The Aukštaitija IMS is located in the east of Lithuania $\left(55^{\circ} 26^{\prime} \mathrm{N}, 26^{\circ} 04^{\prime} \mathrm{E}\right)$ and the Žemaitija IMS is located in the west of Lithuania $\left(56^{\circ} 00^{\prime} \mathrm{N}, 21^{\circ} 52^{\prime} \mathrm{E}\right)$. The distance between the stations is about $300 \mathrm{~km}$.

The aerosol particle samples were collected at the Aukštaitija IMS from June 2007 through December 2008. The bulk precipitation samples were collected at both stations every week during the pe-

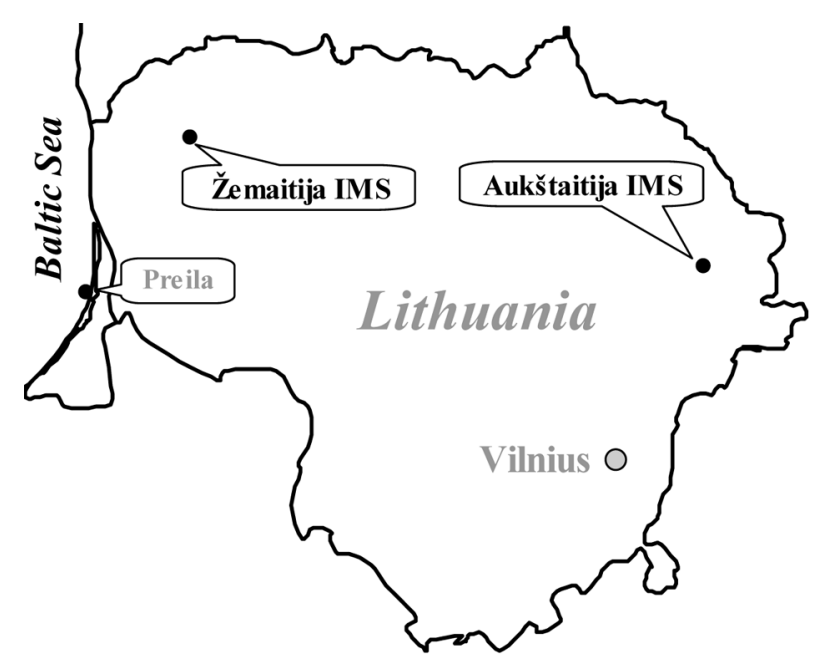

Fig. 1. Scheme of location of sampling stations in Lithuania.

riod 2006-2010. Three bulk collectors were used at each station. Measurement data from three parallel collectors were averaged to avoid the influence of accidental contamination on the final results.

\subsection{Preparation procedures for sampling and analysis}

Bulk collectors, $1000 \mathrm{ml}$ polyethylene bottles, with funnels $8.15 \mathrm{~cm}$ in diameter and $52.15 \mathrm{~cm}^{2}$ in area were used for sampling of precipitation. Before use, the funnels and bottles were initially soaked in the 
$5 \% \mathrm{HNO}_{3}$ water solution for three days and later in the $1 \% \mathrm{HNO}_{3}$ water solution for one week. After the above-mentioned procedures they were rinsed with de-ionized water, dried, packed and thus made ready for use. After collection of precipitation, the super clean $\mathrm{HNO}_{3}$ was added in the collectors to have acid concentration equal to $0.2 \%$ per sample and after 24 hours the solution was poured out into clean bottles for storage in the refrigerator at $5{ }^{\circ} \mathrm{C}$ temperature. Before storage, the amount of precipitation was registered. The preparation procedure of used collectors was the same as presented above.

The total atmospheric aerosol particles were collected on Whatman filters using a pump and the air flow rate of $1 \mathrm{~m}^{3} / \mathrm{h}$. The filters were changed every three days. After mineralization (digestion of exposed filters with $\mathrm{HNO}_{3}$ acid) the aerosol samples were ready for analysis. A detailed description of the preparation procedure for sampling is presented in [29].

\subsection{Instruments}

Concentration of heavy metals in precipitation and aerosol particle samples after preparation were ana- lysed using the Perkin-Elmer Zeeman 3030 atomic absorption spectrometer. Standard reference materials (NIST 1575 and NIST 1547) were used for checking the calibration procedure. The measurement methodologies were tested every year by EMEP international intercalibration exercises. The results from intercalibration exercises showed that analytical methods used for analysis of environmental samples give reliable and representative results. Detailed information on the procedure of measurements is presented in our previous papers [12-14, 18-19, 25, 29].

\section{Results and discussion}

\subsection{Comparison of average concentration of heavy metals at both stations}

The data on monthly average heavy metal concentrations in the air of the Aukštaitija IMS differed 3-10 times during the investigation period. Concentration values in precipitation at each station and between stations varied more significantly (see Table 1). A large disproportion between heavy metal concentrations in the air and

Table 1. Minimal, average and maximal values of monthly heavy metal concentrations in the air, precipitation and deposited amounts at Aukštaitija IMS and Žemaitija IMS (2006-2010).

\begin{tabular}{|c|c|c|c|c|c|c|c|c|c|c|}
\hline \multicolumn{11}{|c|}{ In air, $\mathrm{ng} \mathrm{m}^{-3}(2007-2008)$} \\
\hline \multicolumn{11}{|c|}{ Aukštaitija IMS } \\
\hline & $\mathrm{Pb}$ & $\mathrm{Zn}$ & $\mathrm{Cr}$ & $\mathrm{Ni}$ & $\mathrm{Cu}$ & $\mathrm{Mn}$ & $\mathrm{Cd}$ & $\mathrm{Fe}$ & As & $\mathrm{Hg}$ \\
\hline Minimal & 0.69 & 3.33 & 0.04 & 0.092 & 0.37 & 0.63 & 0.030 & 6.80 & 0.080 & \\
\hline Average & 3.38 & 7.70 & 0.15 & 0.277 & 0.85 & 3.31 & 0.105 & 39.1 & 0.272 & \\
\hline Maximal & 6.22 & 13.9 & 0.27 & 0.440 & 1.25 & 6.65 & 0.305 & 73.9 & 0.520 & \\
\hline \multicolumn{11}{|c|}{ In precipitation, $\mu \mathrm{g} \mathrm{l}^{-1}$} \\
\hline \multicolumn{11}{|c|}{ Aukštaitija IMS } \\
\hline Minimal & 0.70 & 3.06 & 0.027 & 0.018 & 0.31 & 0.218 & 0.029 & 19.2 & 0.047 & 0.0024 \\
\hline Average & 3.54 & 15.3 & 0.429 & 0.703 & 2.35 & 4.74 & 0.129 & 106 & 0.267 & 0.0112 \\
\hline Maximal & 14.1 & 59.7 & 2.11 & 2.34 & 6.69 & 22.1 & 0.661 & 406 & 1.840 & 0.0290 \\
\hline \multicolumn{11}{|c|}{ Žemaitija IMS } \\
\hline Minimal & 0.266 & 2.71 & 0.036 & 0.014 & 0.146 & 1.11 & 0.013 & 6.02 & 0.006 & 0.0035 \\
\hline Average & 6.47 & 38.4 & 0.490 & 2.23 & 5.64 & 8.45 & 0.155 & 132 & 0.264 & 0.0092 \\
\hline Maximal & 31.9 & 551 & 2.64 & 16.7 & 34.9 & 57.8 & 1.31 & 1227 & 1.65 & 0.0214 \\
\hline \multicolumn{11}{|c|}{ Deposited amounts, $\mu \mathrm{g} \mathrm{m}^{-2} \mathrm{month}^{-1}$} \\
\hline \multicolumn{11}{|c|}{ Aukštaitija IMS } \\
\hline Minimal & 9.50 & 59.0 & 1.10 & 1.34 & 14.6 & 9.7 & 0.437 & 222 & 0.553 & 0.07 \\
\hline Average & 168 & 699 & 20.2 & 34.9 & 110 & 235 & 6.39 & 4520 & 12.6 & 0.63 \\
\hline Maximal & 1040 & 2290 & 167 & 262 & 395 & 1340 & 36.9 & 22500 & 139 & 1.99 \\
\hline \multicolumn{11}{|c|}{ Žemaitija IMS } \\
\hline Minimal & 27.6 & 73.3 & 2.21 & 2.92 & 6.32 & 33.8 & 0.635 & 515 & 0.410 & 0.035 \\
\hline Average & 673 & 3110 & 38.4 & 217 & 498 & 639 & 17.8 & 8190 & 28.4 & 1.13 \\
\hline Maximal & 7430 & 19100 & 135 & 1050 & 2700 & 2720 & 136 & 31900 & 219 & 3.58 \\
\hline
\end{tabular}


in precipitation can be explained by irregularity, duration and amount of precipitation during the sampling period. Usually, concentration of heavy metals is higher during short-term than longterm precipitation: the main amount of heavy metals is washed out during the first minutes of rain or snow [30]. The average concentration in precipitation and the deposited amount of heavy metals were higher at the Žemaitija IMS (Table 1). This can be explained by air masses more polluted with heavy metals in the western part of Lithuania and by a higher average yearly amount of precipitation at the Žemaitija IMS (about $1220 \mathrm{~mm}$ ) than at the Aukštaitija IMS (about $670 \mathrm{~mm}$ ) (IMS data, 2006-2010).

During the investigation period, the trends of concentrations of heavy metals in the air, in precipitation and in the area unit deposited with precipitation were established. To confirm the reliability of trends, the correlation coefficients of concentrations of heavy metals in the air, in precipitation and in deposited amounts over the sampling time were calculated and are presented in Table 2. Based on the calculation data, the heavy metals with reliable tendencies were determined. The reliability of correlative relation was evaluated based on data presented in [31]. For heavy metals parameters $\left(k, C_{0}, \alpha, Q_{0}\right)$ of linear regression equations were calculated (Table 3 ).

The measurement period of heavy metals in the air at the Aukštaitija IMS was relatively short, thus only a decreasing tendency of $\mathrm{Cd}$ concentration was identified. A decreasing trend of concentration in precipitation was observed for $\mathrm{Pb}$ at both stations and for $\mathrm{Fe}$ at the Aukštaitija IMS. Increasing trends were observed for $\mathrm{Cr}, \mathrm{Ni}$ and $\mathrm{Cu}$ at both stations and for $\mathrm{Hg}$ only at the Žemaitija IMS. An increasing trend of deposited amounts with precipitation for $\mathrm{Cr}, \mathrm{Ni}$ and $\mathrm{Cu}$ was observed at both stations and for Mn only at the Žemaitija IMS.

A linear regression equation for heavy metal concentration in precipitation is

$$
C=k \cdot t+C_{0}
$$

Table 2. Correlation coefficients between heavy metal concentrations in the air, precipitation and deposited amounts over time.

\begin{tabular}{|c|c|c|c|c|c|c|c|c|c|}
\hline \multicolumn{10}{|c|}{ In air } \\
\hline \multicolumn{10}{|c|}{ Aukštaitija IMS } \\
\hline $\mathrm{Pb}$ & $\mathrm{Zn}$ & $\mathrm{Cr}$ & $\mathrm{Ni}$ & $\mathrm{Cu}$ & Mn & Cd & $\mathrm{Fe}$ & As & $\mathrm{Hg}$ \\
\hline-0.116 & -0.150 & -0.141 & 0.377 & -0.002 & -0.116 & -0.539 & -0.086 & -0.037 & \\
\hline \multicolumn{10}{|c|}{ In precipitation } \\
\hline \multicolumn{10}{|c|}{ Aukštaitija IMS } \\
\hline-0.340 & -0.186 & 0.559 & 0.428 & 0.333 & 0.087 & -0.076 & -0.404 & -0.246 & -0.081 \\
\hline \multicolumn{10}{|c|}{ Žemaitija IMS } \\
\hline-0.422 & -0.201 & 0.464 & 0.439 & 0.449 & 0.249 & -0.060 & -0.284 & -0.017 & -0.327 \\
\hline \multicolumn{10}{|c|}{ In deposited amounts } \\
\hline \multicolumn{10}{|c|}{ Aukštaitija IMS } \\
\hline-0.110 & -0.045 & 0.575 & 0.453 & 0.455 & 0.198 & 0.000 & -0.215 & -0.195 & 0.013 \\
\hline \multicolumn{10}{|c|}{ Žemaitija IMS } \\
\hline-0.230 & -0.159 & 0.594 & 0.419 & 0.414 & 0.434 & -0.046 & 0.011 & -0.117 & 0.229 \\
\hline
\end{tabular}

Table 3. Coefficients calculated from regression equations.

\begin{tabular}{|c|c|c|c|c|c|c|c|c|}
\hline \multirow{3}{*}{ Element } & \multicolumn{4}{|c|}{ Average concentration in precipitation, $\mu \mathrm{g}{ }^{-1}$} & \multicolumn{4}{|c|}{ Average deposited amounts, $\mu \mathrm{g} \mathrm{m}^{-2} \mathrm{month}^{-1}$} \\
\hline & \multicolumn{2}{|c|}{ Aukštaitija IMS } & \multicolumn{2}{|c|}{ Žemaitija IMS } & \multicolumn{2}{|c|}{ Aukštaitija IMS } & \multicolumn{2}{|c|}{ Žemaitija IMS } \\
\hline & $k$ & $C_{0}$ & $k$ & $C_{0}$ & $a$ & $Q_{0}$ & $a$ & $Q_{0}$ \\
\hline $\mathrm{Pb}$ & -0.694 & 5.28 & -1.88 & 11.2 & & & & \\
\hline $\mathrm{Cr}$ & 0.165 & 0.015 & 0.142 & 0.135 & 8.52 & 1.25 & 13.1 & 5.67 \\
\hline $\mathrm{Ni}$ & 0.149 & 0.330 & 0.822 & 0.171 & 12.3 & 4.14 & 73.5 & 33.4 \\
\hline $\mathrm{Cu}$ & 0.324 & 1.54 & 1.80 & 1.15 & 28.5 & 38.7 & 150 & 123 \\
\hline $\mathrm{Fe}$ & -23.8 & 166 & & & & & & \\
\hline $\mathrm{Mn}$ & & & & & & & 193 & 155 \\
\hline
\end{tabular}


where $C$ is the heavy metal concentration in precipitation, $k$ is the annual concentration alteration, $C_{0}$ is the concentration from $2006, t$ is time from the beginning of 2006 .

A linear regression equation for deposited amounts of heavy metals with precipitation per month is

$$
Q=a \cdot t+Q_{0},
$$

where $Q$ is the deposited amount of heavy metals to $\mathrm{m}^{2}$ per month, $\alpha$ is the annual amount alteration, $Q_{0}$ is the deposited amount of heavy metals to $\mathrm{m}^{2}$ per month from the beginning of 2006.

The variation of regression coefficient values of heavy metals is presented in Table 3 . The values are presented only for those heavy metals whose correlation coefficients show a reliable relation. Table 3 does not include regression coefficients of Cd concentration in the air over time; they are equal to $k=-0.09 \mathrm{ng} \mathrm{m}^{-3} \mathrm{y}^{-1}$ and $C_{0}=0.173 \mathrm{ng} \mathrm{m}^{-3}$.

\subsection{Trends of heavy metals}

$\mathrm{Pb}, \mathrm{Cr}$ and $\mathrm{Ni}$ concentration courses and trends in precipitation at the Aukštaitija IMS and Žemaitija IMS are presented in Fig. 2. Deposited amounts of $\mathrm{Cr}$ and $\mathrm{Ni}$ at both IMSs are presented in Fig. 3. A remarkable increasing of $\mathrm{Cr}$ and $\mathrm{Ni}$ concentrations from the beginning of 2007 can be seen in Figs. 2 and 3, and it is clearly evident at the Žemaitija IMS. It is hard to relate it with polluted air mass transfer because monthly precipitation amounts were used, while air mass transfer directions were very changeable during a month.
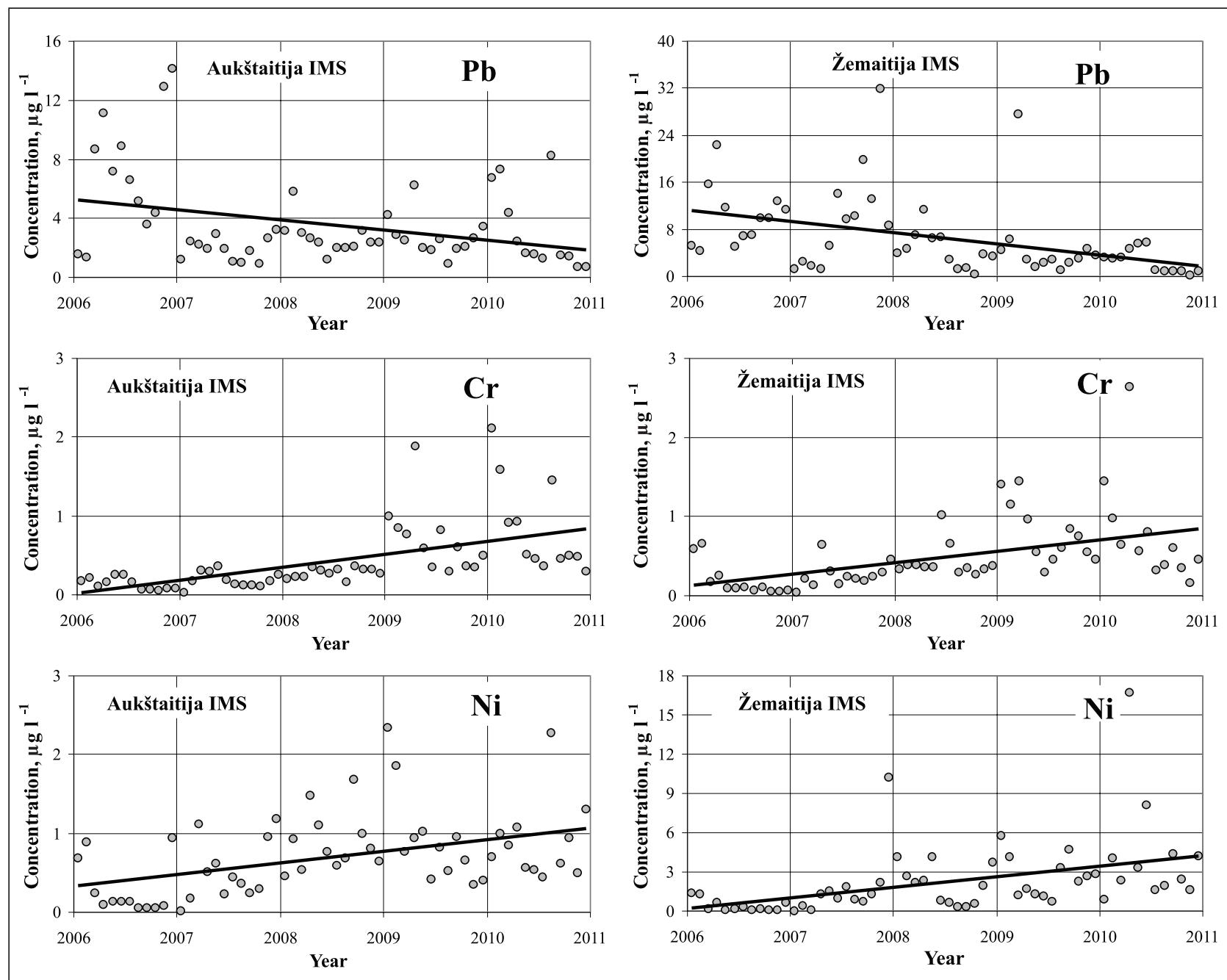

Fig. 2. Trends of $\mathrm{Pb}, \mathrm{Cr}$ and Ni concentrations in precipitation at Aukštaitija IMS and Žemaitija IMS. 


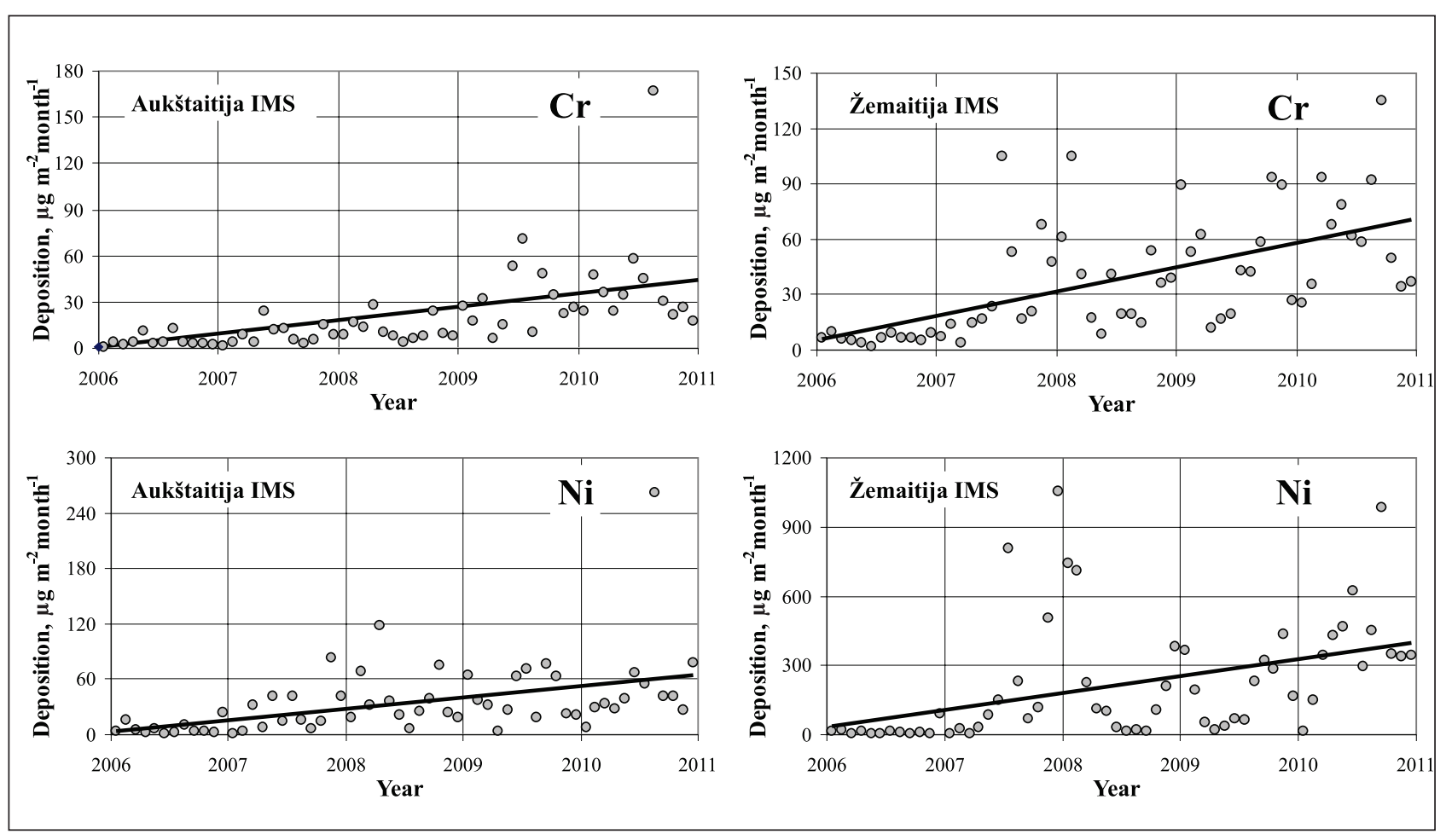

Fig. 3. Trends of deposited amounts of Cr and Ni at Aukštaitija IMS and Žemaitija IMS.

The trends of most deposited heavy metals for the territory of Lithuania were similar at both stations. Our previous investigations of $\mathrm{Pb}, \mathrm{Cr}$ and $\mathrm{Ni}$ concentrations in mosses showed a clear decreasing trend during 1995-2005 [25]; however, the results of our current investigation in precipitation show a contrary trend. We can possibly assume that further research of $\mathrm{Cr}$ and $\mathrm{Ni}$ in mosses will show an increasing trend of these metals as well.

\subsection{Seasonal variations of heavy metal monthly concentration}

We consider that the irregularity and different distribution of precipitation over the territory of Lithuania during the investigation period (see Fig. 4) had a large influence on determination of trends of heavy metals.

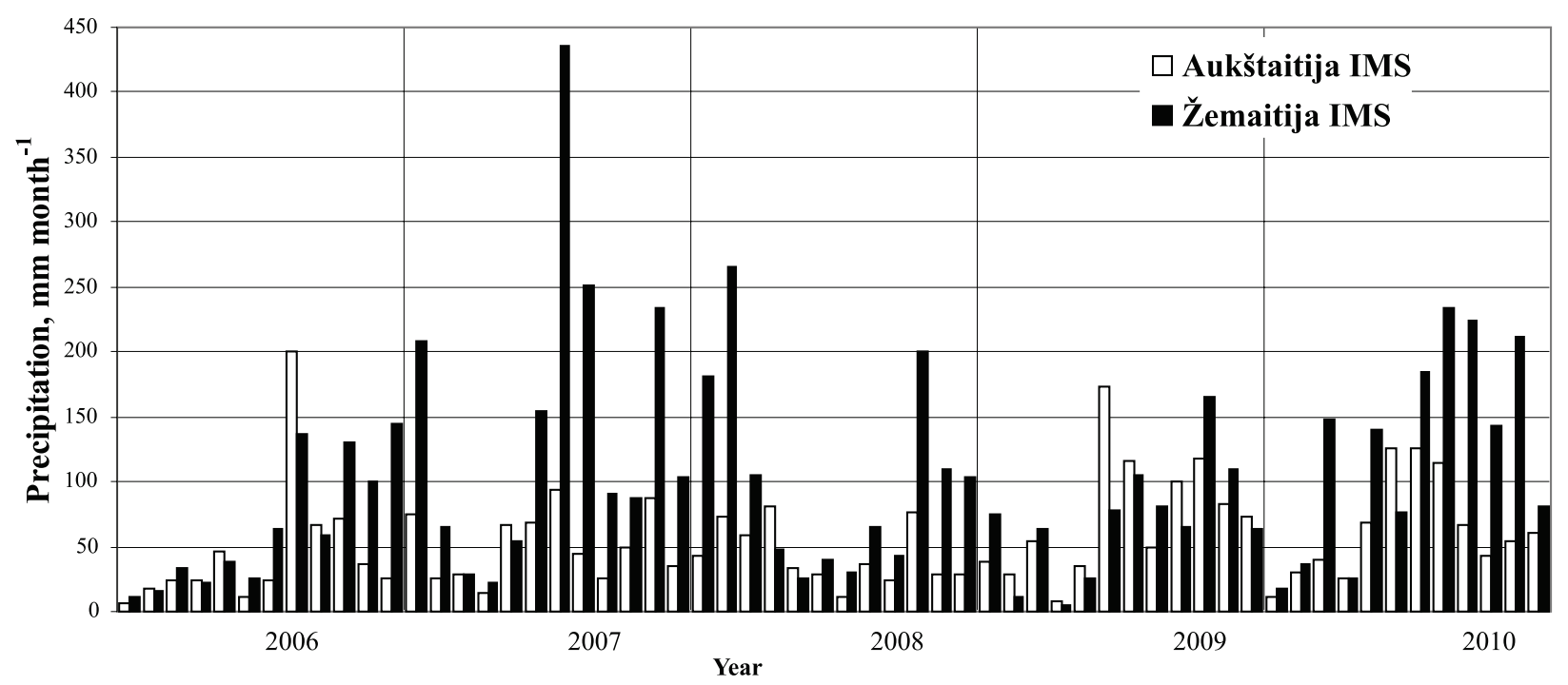

Fig. 4. Average monthly precipitation amounts at Aukštaitija IMS and Žemaitija IMS. 


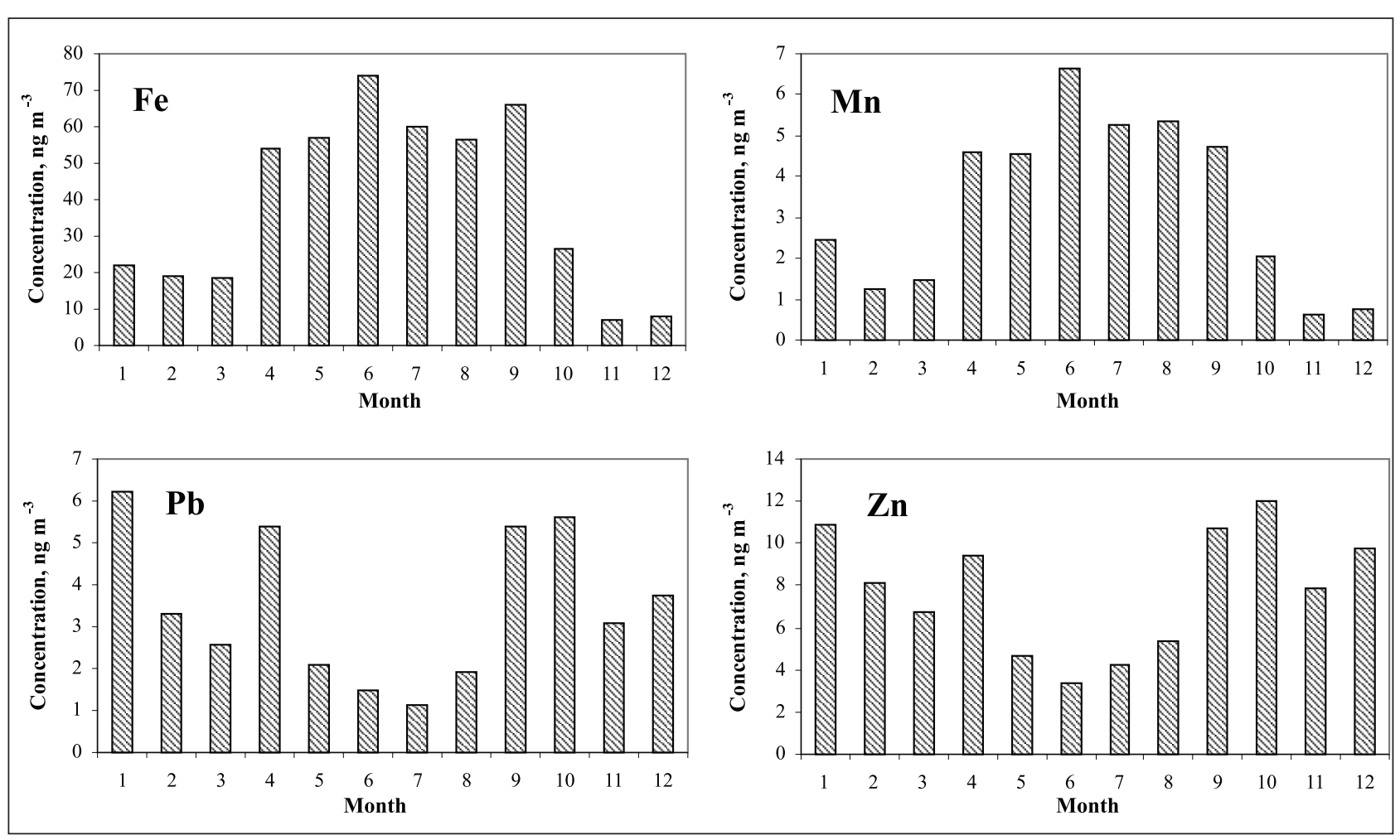

Fig. 5. Average monthly concentrations of $\mathrm{Fe}, \mathrm{Mn}, \mathrm{Pb}$ and $\mathrm{Zn}$ in the air at the Aukštaitija IMS (2007-2008).

A comparison of the seasonal variation of heavy metals in the air and in precipitation showed that concentration variations in the air were more clearly expressed than in precipitation (see Fig. 5).

A comparison shows that Fe and Mn (natural origin) and $\mathrm{Pb}$ and $\mathrm{Zn}$ (anthropogenic origin) have a contrary seasonal variation (Fig. 5). Fe and Mn are emitted to the atmosphere and their concentrations in the air are higher during the warm season. For elements of anthropogenic origin, higher concentrations in the air are observed during the cold period because of larger fuel consumption during the heating season, decreased turbulent air mixing, and different air mass transfer frequency. The analysis of air mass backward trajectories shows that most frequently air masses are coming to Lithuania from west and northwest [15]. The lowest frequency distribution is for the air masses coming to Lithuania from east and south. Such a clear seasonal variation in the air as described above is not observed for heavy metal concentrations in precipitation or deposited amounts (see Fig. 6). The main reason is precipitation irregularity and different distribution on the Lithuanian territory.
Correlation coefficients of heavy metal concentrations in precipitation at the Aukštaitija IMS and Žemaitija IMS are presented in Table 4. Common correlating element groups for both stations are identified and marked in bold in the table: As-Cd, $\mathrm{Ni}-\mathrm{Cr}-\mathrm{Cu}$, and $\mathrm{Mn}-\mathrm{Cu}$. Probably, the above-mentioned groups are typical of the entire territory of Lithuania and are caused by long-range transfer of air masses. Monthly concentrations of heavy metals $\mathrm{Pb}, \mathrm{Zn}, \mathrm{Cr}, \mathrm{Ni}, \mathrm{Cu}, \mathrm{Cd}$ and $\mathrm{As}$ in the air at the Aukštaitija IMS were measured in 19 samples. Concentrations of $\mathrm{Fe}$ and $\mathrm{Mn}$ were measured throughout the year 2008 (12 samples). Two heavy metal groups with strong correlation can be selected from these measurement data: $\mathrm{Zn}-\mathrm{Pb}-\mathrm{As}$ (correlation coefficient $0.878-0.968$ ) and Fe-Mn (correlation coefficient 0.980 ).

Correlation coefficients between concentrations of $\mathrm{Mn}$ and $\mathrm{Fe}$ in the air and in precipitation are 0.577 and 0.650 , respectively. Data analysis shows that these correlating groups do not have recurrence for heavy metal concentrations in the air and the deposited amount. This can be explained by a different amount of data obtained at the stations: only $12-19$ measurements in the air 


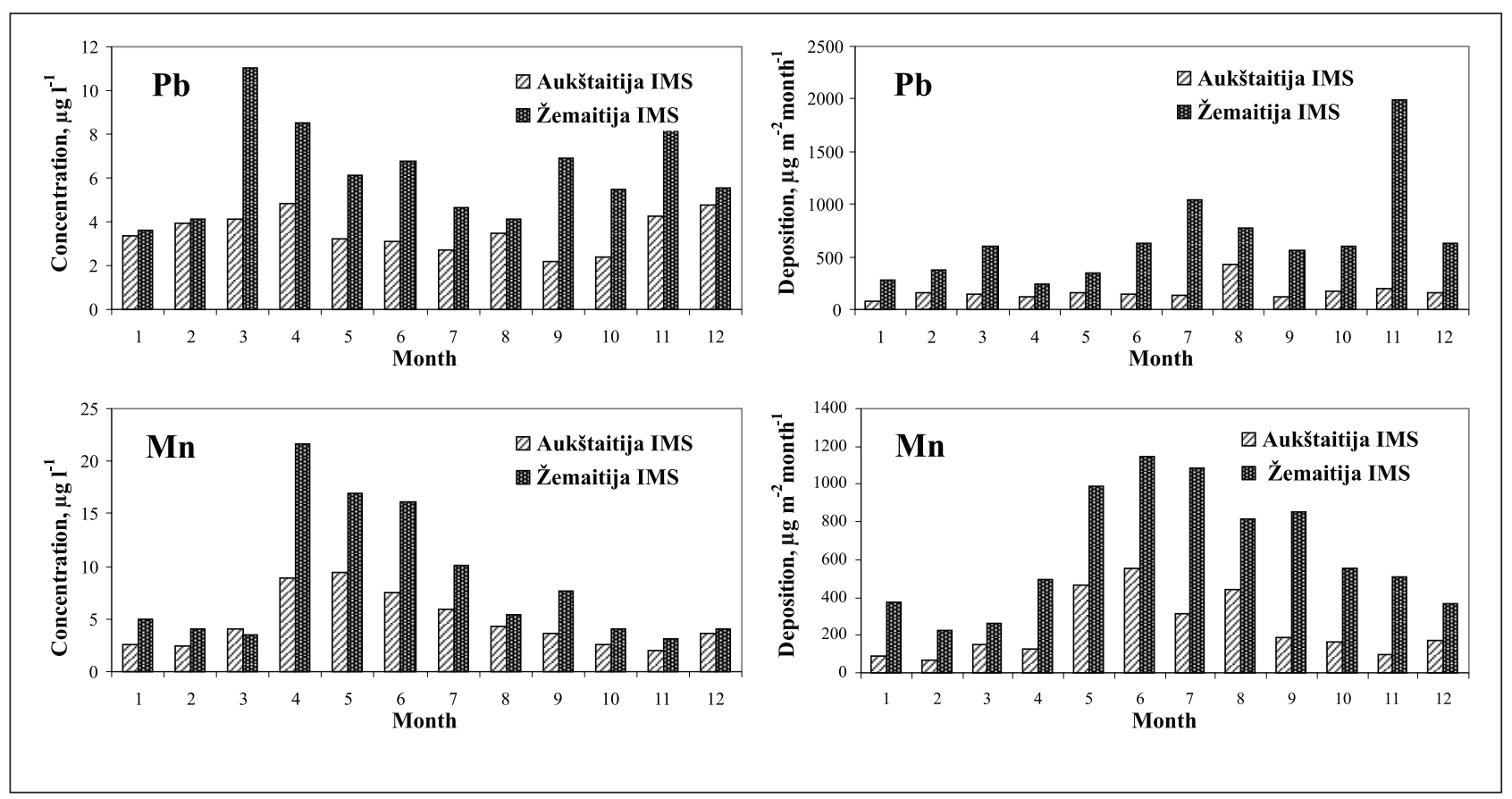

Fig. 6. Average monthly concentrations in precipitation and deposited amounts of $\mathrm{Pb}$ and $\mathrm{Mn}$ at Aukštaitija IMS and Žemaitija IMS (2006-2010).

Table 4. Correlation coefficients of heavy metal concentrations in precipitation at Aukštaitija IMS and Žemaitija IMS. Numbers in bold indicate reliable correlation.

\begin{tabular}{|c|c|c|c|c|c|c|c|c|c|c|}
\hline \multicolumn{11}{|c|}{ Aukštaitija IMS } \\
\hline & $\mathbf{P b}$ & $\mathrm{Zn}$ & $\mathrm{Cr}$ & $\mathrm{Ni}$ & $\mathrm{Cu}$ & Mn & Cd & $\mathrm{Fe}$ & As & $\mathrm{Hg}$ \\
\hline $\mathbf{P b}$ & 1.000 & -0.008 & 0.148 & -0.071 & -0.204 & 0.038 & 0.059 & 0.221 & 0.111 & 0.110 \\
\hline $\mathrm{Zn}$ & & 1.000 & -0.104 & 0.424 & 0.462 & 0.095 & 0.251 & 0.548 & 0.410 & 0.278 \\
\hline $\mathrm{Cr}$ & & & 1.000 & 0.487 & 0.505 & 0.314 & 0.229 & -0.163 & -0.040 & -0.033 \\
\hline $\mathrm{Ni}$ & & & & 1.000 & 0.557 & 0.013 & 0.305 & -0.037 & 0.165 & 0.041 \\
\hline $\mathrm{Cu}$ & & & & & 1.000 & 0.418 & 0.249 & 0.163 & 0.135 & 0.162 \\
\hline Mn & & & & & & 1.000 & 0.240 & 0.325 & 0.020 & -0.063 \\
\hline Cd & & & & & & & 1.000 & -0.037 & 0.702 & -0.262 \\
\hline $\mathrm{Fe}$ & & & & & & & & 1.000 & 0.114 & 0.391 \\
\hline As & & & & & & & & & 1.000 & -0.070 \\
\hline $\mathrm{Hg}$ & & & & & & & & & & 1.000 \\
\hline \multicolumn{11}{|c|}{ Žemaitija IMS } \\
\hline & $\mathrm{Pb}$ & $\mathrm{Zn}$ & $\mathrm{Cr}$ & $\mathrm{Ni}$ & $\mathrm{Cu}$ & Mn & Cd & $\mathrm{Fe}$ & As & $\mathrm{Hg}$ \\
\hline $\mathbf{P b}$ & 1.000 & -0.014 & -0.089 & -0.124 & -0.161 & -0.136 & 0.298 & 0.001 & 0.052 & -0.392 \\
\hline $\mathrm{Zn}$ & & 1.000 & 0.077 & 0.129 & 0.173 & 0.110 & 0.206 & 0.095 & 0.144 & -0.214 \\
\hline $\mathrm{Cr}$ & & & 1.000 & 0.668 & 0.772 & 0.511 & 0.041 & 0.191 & 0.328 & 0.195 \\
\hline $\mathrm{Ni}$ & & & & 1.000 & 0.866 & 0.566 & 0.492 & 0.178 & 0.741 & 0.054 \\
\hline $\mathrm{Cu}$ & & & & & 1.000 & 0.624 & 0.202 & 0.126 & 0.583 & -0.003 \\
\hline Mn & & & & & & 1.000 & 0.083 & 0.229 & 0.435 & 0.169 \\
\hline $\mathrm{Cd}$ & & & & & & & 1.000 & -0.001 & 0.649 & -0.242 \\
\hline $\mathrm{Fe}$ & & & & & & & & 1.000 & 0.372 & 0.260 \\
\hline As & & & & & & & & & 1.000 & -0.012 \\
\hline $\mathrm{Hg}$ & & & & & & & & & & 1.000 \\
\hline
\end{tabular}


Table 5. Average concentration of heavy metals in the air, $\mathrm{ng} \mathrm{m}^{-3}$ (2007-2008).

\begin{tabular}{ccccccccc|c|c|c}
\hline & $\mathbf{P b}$ & $\mathbf{Z n}$ & $\mathbf{C r}$ & $\mathbf{N i}$ & $\mathbf{C u}$ & $\mathbf{M n}$ & $\mathbf{C d}$ & $\mathbf{A s}$ & $\mathbf{F e}$ \\
\hline Preila EMEP station & 5.47 & 14.5 & 0.318 & 0.803 & 1.84 & 3.35 & 0.127 & 0.476 & 50.1 \\
\hline Aukštaitija IMS & 3.36 & 7.63 & 0.150 & 0.282 & 0.851 & 3.32 & 0.102 & 0.270 & 39.1 \\
\hline
\end{tabular}

at the Aukštaitija IMS were performed, and about 40-60 measurements of heavy metal concentrations in precipitation were performed at both stations. Another reason for the absence of the abovementioned recurrence is different distribution of elements on different-size aerosol particles, which can impact different washout effectiveness from the atmosphere [11]. The third reason is the alreadymentioned irregularity of precipitation, e. g. different intensity and distribution at both stations during the investigation time.

Because the measurements of heavy metals in the air were performed only at the Aukštaitija IMS, for comparison of results we used the heavy metal data in the air from the Preila EMEP background station which is located only $85 \mathrm{~km}$ away from the Žemaitija IMS in the western part of Lithuania. The data obtained at this station during the same period (from the beginning of June 2007 till the end of 2008) can be used to compare heavy metal concentrations in the air of eastern and western parts of Lithuania (see Table 5).

It can be seen in Table 5 that heavy metal concentrations in the air are remarkably higher in the western part of Lithuania, as was stated above.

\section{Conclusions}

A higher deposited amount of heavy metals on the earth was observed in the western part of Lithuania (at the Žemaitija IMS) compared with the eastern part of Lithuania (at the Aukštaitija IMS). This difference was probably due to a higher concentration of heavy metals in the air and a higher amount of precipitation in the western part of Lithuania. A decreasing trend of $\mathrm{Pb}$ concentration in precipitation and an increasing trend for $\mathrm{Cr}, \mathrm{Ni}$ and $\mathrm{Cu}$ in precipitation and deposited amounts were observed at both stations. Heavy metal concentrations in the air had seasonal variation at the Aukštaitija IMS. Concentrations of natural origin elements ( $\mathrm{Fe}$ and $\mathrm{Mn}$ ) were higher during the warm period, while anthropogenic origin elements $(\mathrm{Pb}, \mathrm{Zn}, \mathrm{Cr}, \mathrm{Ni}, \mathrm{Cu}$,
$\mathrm{Cd}, \mathrm{As}, \mathrm{Hg}$ ) had higher concentrations during the cold period. The common correlating groups of elements for both stations were established: As-Cd, $\mathrm{Ni}-\mathrm{Cr}-\mathrm{Cu}$ and $\mathrm{Mn}-\mathrm{Cu}$. These groups are probably typical of the entire territory of Lithuania and are caused by long-range transfer of air masses. For confirmation of the above conclusion, further investigations are needed.

\section{Acknowledgements}

This work was supported by the Lithuanian Environmental Protection Agency under contract No. 4F10-71.

\section{References}

[1] W. Salomons and U. Forstner, Metals in the Hydrocycle (Springer-Verlag, Berlin, 1984).

[2] J.N. Galloway, J.D. Thornton, S.A. Norton, H.L. Volchok, and R.A.N. McLean, Trace metals in atmospheric deposition - a review and assessment, Atmos. Environ. 16, 1677-1700 (1982).

[3] W.H. Schroeder, M. Dobson, D.M. Kane, and N.D. Johnson, Toxic trace elements associated with airborne particulate matter - a review, J. Air Pollut. Contr. Assoc., 37, 1267-1285 (1987).

[4] H. Ross, Trace metals in precipitation in Sweden, Water Air Soil Pollut. 36, 349-363 (1987).

[5] T. Berg, O. Royset, and E. Steines, Trace elements in atmospheric precipitation at Norwegian background stations (1989-1990) measured by ICPMS, Atmos. Environ. 28(21), 3519-3536 (1994).

[6] Å. Iverfeldt, J. Munthe, C. Brosset, and J. Pacyna, Long-term changes in concentration and deposition of atmospheric mercury over Scandinavia, Water Air Soil Pollut. 80, 227-233 (1995).

[7] D. Schwela, Air pollution and health in urban areas, Rev. Environ. Health 15, 13-42 (2000).

[8] J. Ovadnevaite, K. Kvietkus, and A. Maršalka, 2002 summer fires in Lithuania: impact on the Vilnius city air quality and the inhabitants health, Sci. Total Environ. 356(1-3), 11-21 (2006).

[9] H. Ross, Precipitation, in: Trace Metals in Natural Waters, eds. B.S. Salbu and E. Steinnes (CRC Press, 1995). 
[10]S. Garnaud, J.M. Mouchel, G. Chebbo, and D.R. Thévenot, Heavy metal concentrations in dry and wet atmospheric deposits in Paris district: comparison with urban runoff, Sci. Total Environ. 235(1-3), 235-245 (1999).

[11]M. Mircea, S. Stefan, and S. Fuzzi, Precipitation scavenging coefficient: influence of measured aerosol and raindrop size distributions, Atmos. Environ. 34(29-30), 5169-5174 (2000).

[12]D. Čeburnis, Qualitative and quantitative estimation of atmospheric trace metal deposition, $\mathrm{PhD}$ thesis (Institute of Physics, Vilnius, Lithuania, 1997).

[13] D. Čeburnis, D. Valiulis, and J. Šakalys, The influence of local processes on trace metal concentrations in long-range transported air masses, Environ. Chem. Phys. 21(1), 31-36 (1999).

[14] J. Šakalys, K. Kvietkus, and D. Valiulis, Variation tendencies of heavy metal concentrations in the air and precipitation, Environ. Chem. Phys. 26(2), 61-67 (2004).

[15]D. Šopauskiené, D. Jasinevičienè, and S. Stapčinskaite, The effect of changes in European anthropogenic emissions on the concentrations of sulphur and nitrogen components in air and precipitation in Lithuania, Water Air Soil Pollut. 130(1-4) (2001), pp. 517-522, http://dx.doi. org/10.1023/A:1013826411072.

[16]Y. Gélinas, M. Luccote, and J.P. Schmit, History of the atmospherics deposition of major trace elements in the industrialized St. Lawrence Valley, Quebec, Canada, Atmos. Environ. 34, 1797-1810 (2000).

[17] . Rühling and G. Tyler, Changes in atmospheric deposition rates of heavy metals in Sweden, Water, Air, Soil Pollut. Focus 1, 311-323 (2001).

[18] D. Čeburnis, J. Šakalys, K. Armolaitis, D. Valiulis, and K. Kvietkus, In-stack emissions of heavy metals estimated by moss biomonitoring method, Atmos. Environ. 36(9), 1465-1474 (2002).

[19] D. Valiulis, D. Čeburnis, J. Šakalys, and K. Kvietkus, Estimation of atmospheric trace metal emissions in Vilnius city, Lithuania, using vertical concentration gradient and road tunnel measurement data, Atmos. Environ. 36(39-40), 6001-6014 (2002).

[20]E. Steinnes, T. Berg, and T.E. Sjobakk, Temporal trends in long-range atmospheric transport of heavy metals to Norway, J. Phys. IV France 107, 1271 (2003), http://dx.doi.org/10.1051/jp4:20030532.

[21] C.S.C. Wong, X.D. Li, G. Zhang, S.H. Qi, and X.Z. Peng, Atmospheric deposition of heavy metals in the Pearl River Delta, China, Atmos. Environ. 37, 767-776 (2003).
[22] E.C. Krug and D. Winstanley, Comparison of mercury in atmospheric deposition and in Illinois and USA soils, Hydrol. Earth Syst. Sci. 8(1), 98-102 (2004).

[23] S. Azimi, V. Rocher, S. Garnaud, G. Varrault, and D. Thevenot, Decrease of atmospheric deposition of heavy metals in an urban area from 1994 to 2002 (Paris, France), Chemosphere 61, 645-651 (2005).

[24] S. Melaku, V. Morris, D. Raghavan, and C. Hosten, Seasonal variation of heavy metals in ambient air and precipitation at a single site in Washington, DC, Environ. Pollut. 155, 88-98 (2007).

[25] J. Šakalys, K. Kvietkus, J. Sucharova, I. Suchara, and D. Valiulis, Changes in total concentrations and assessed background concentrations of heavy metals in moss in Lithuania and the Czech Republic between 1995 and 2005, Chemosphere 76(1), 91-97 (2009).

[26] J.M. Caffrey, W.M.Landing, S.D. Nolek, K.J. Gosnell, S.S. Bagui, and S.C. Bagui, Atmospheric deposition of mercury and major ions to the Pensacola (Florida) watershed: spatial, seasonal, and interannual variability, Atmos. Chem. Phys. 10, 54255434 (2010).

[27]H. Harmens, D.A. Norris, E. Steinnes, E. Kubin, J. Piispanen, R. Alber, Y. Aleksiayenak, O. Blum, M. Coşkun, M. Dam, L. De Temmerman, J.A. Fernández, M. Frolova, M. Frontasyeva, L. González-Miqueo, K. Grodzińska, Z. Jeran, S. Korzekwa, M. Krmar, K. Kvietkus, S. Leblond, S. Liiv, S.H. Magnússon, B. Maňkovská, R. Pesch, Å. Rühling, J.M. Santamaria, W. Schröder, Z. Spiric, I. Suchara, L. Thöni, V. Urumov, L. Yurukova, and H.G. Zechmeister, Mosses as biomonitors of atmospheric heavy metal deposition: spatial and temporal trends in Europe, Environ. Pollut. 158, 3144-3156 (2010).

[28]B.S. Davis and G.F. Birch, Spatial distribution of bulk atmospheric deposition of heavy metals in Metropolitan Sydney, Australia, Water, Air, Soil Pollut. 214, 147-162 (2011), http://dx.doi. org/10.1007/s11270-010-0411-3.

[29]D. Čeburnis, Atmospheric trace metal deposition in Lithuania: methods and estimation, in: Heavy Metals in the Environment: an Integrated Approach, ed. D.A. Lovejoy (Vilnius, Lithuania, 1999), pp. 5-15.

[30]J. Šakalys, J. Švedkauskaitè, and D. Valiulis, Estimation of heavy metal washout from the atmosphere, Environ. Chem. Phys, 25(1), 16-22 (2003).

[31] R.R. Socal and F.J. Rohlf, Introduction to Biostatistics (W.H. Freeman \& Company, New York, 1987), pp. 322-328. 


\title{
SUNKIŲJŲ METALŲ NUSĖDIMO IŠ ATMOSFEROS TENDENCIJOS LIETUVOJE
}

\author{
K. Kvietkus, J. Šakalys, D. Valiulis
}

Fizinių ir technologijos mokslu centras, Vilnius, Lietuva

\section{Santrauka}

Pateikti ilgalaikių sunkiụjų metalų $(\mathrm{Pb}, \mathrm{Zn}, \mathrm{Cr}$, $\mathrm{Ni}, \mathrm{Cu}, \mathrm{Mn}, \mathrm{Cd}, \mathrm{Fe}, \mathrm{As}, \mathrm{Hg}$ ) koncentracijų matavimų Aukštaitijos ir Žemaitijos integruoto monitoringo stotyse (IMS) rezultatai. Vidutinès metinès sunkiụjų metalų koncentracijos ore ir krituliuose eigos analizé pateikta 2006-2010 metams. Vakarinèje Lietuvos dalyje nustatyta didesnè žemès paviršiaus apkrova sunkiaisiais metalais negu rytineje dalyje. Tikriausiai šis paviršiaus apkrovos skirtumas susidarè dèl didesnès sunkiụjų metalų koncentracijos ore ir didesnio kritulių kiekio vakarinejje Lietuvos dalyje. Stebèta $\mathrm{Pb}$ koncentracijos krituliuose mažèjimo tendencija abiejose IMS bei $\mathrm{Cr}$, Ni ir $\mathrm{Cu}$ koncentracijos krituliuose ir iškritose ¡ žemès paviršiu didejimo tendencija abiejose stotyse. Nustatytos bendros koreliuojančiu metalų As-Cd, $\mathrm{Ni}-\mathrm{Cr}-\mathrm{Cu}$ ir $\mathrm{Mn}-\mathrm{Cu}$ koncentracijų grupès abiems stotims. Tikimiausia, kad šios grupès yra būdingos visai Lietuvos teritorijai ir yra nulemtos tolimosios oro masių pernašos. 